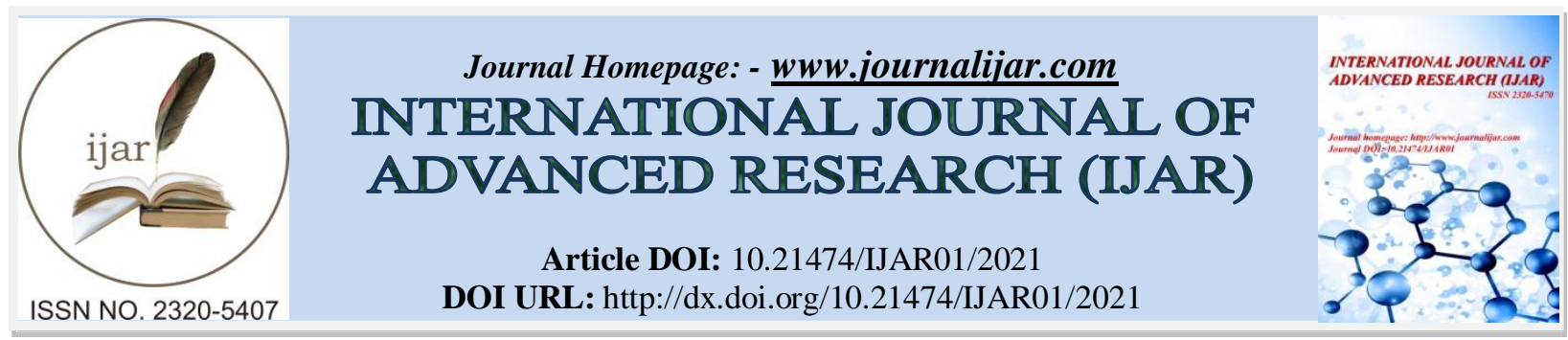

RESEARCH ARTICLE

\title{
DIETARY PATTERNS AMONG MEDICAL STUDENT IN IMAM MOHAMMED BIN SAUD ISLAMIC UNIVERSITY.
}

Alqumaizi Khaled, Almaymn Abdularhman Ibrahim, Alqarni Abdullah Ali and Alharmaly Abdullah Hasan. Collage of medicine at Al-Imam Mohammed Saud university, Othman bin Affan Road, Al -Nada neighborhood, Riyadh 13317 Phone: 0112037100.

\section{Manuscript Info}

Manuscript History

Received: 25 September2016

Final Accepted: 9 October 2016

Published: October 2016

Key words:-

\section{Abstract}

The purpose of this research is to is to know the what are the variant types dietary patterns of students of college of medicine in imam Mohammed bin Saud Islamic university in relation to obesity and overweight mainly among first, second and third year. World widely there were many studies discussing this issue but there is no study on medical students so we Deeside to do a study on medical students and We conducted a cross-sectional study using an electronic questioner paper and distributed by email . From our study we found that the prevalence of obesity and overweight was high by $57.5 \%(65.4 \%$, $52.6 \%$ and $54.3 \%$ of $1 \mathrm{st}, 2$ nd and 3rd years) And it's a growing problem among all patches .

Copy Right, IJAR, 2016,. All rights reserved.

\section{Introduction:-}

Dietary patterns are frameworks that people tend to follow when making choices about what to eat. A number of factors can dictate what people eat and many of these factors overlap in various ways. When treating a patient with a medical condition that appears to be related to dietary choices, it can be important to understand the patterns that a patient follows. But what we always tend to forget is the dietary habitat among the medical student who will become one day physicians intervening this process of promoting health to the community. We really believe that, the lack of healthy dietary habit among medical student will has a direct effect on the community in the long term.

A Survey done in tow medical colleges in Southern India shows that there's a dramatically increase of the fatty acid daily consumption among their student. There're so many similar researches done in different colleges of different specialties that show similar results as well.

We claim this high prevalence of the poor healthy dietary habitat may due to the long hours that these students spend in the collage, increasing the chance of more fast food consumption. Or it may related to the amount of stress these student are facing.

That's why we are very interested to estimate the dietary patterns among the medical student at Al-Imam University. As away to promote a better life style among these student.

Corresponding Author:- Alqumaizi Khaled.

Address:- Collage of medicine at Al-Imam Mohammed Saud university, Othman bin Affan Road, Al -

Nada neighborhood, Riyadh 13317 Phone: 0112037100. 
1. To measure the overweight and obesity prevalence among preclinical medical student at Al-Imam university.

2. To study the food consumption among the targeted population.

3. To determine the relationship between the food consumption and, the overweight and obesity in this population.

4. To increase the Awareness of preclinical medical students about the prevalence of obesity and overweight among them." reference: from the result of the research"

5. To increase the Awareness of preclinical medical students about the relationship between the food consumption and, the overweight and obesity if it is there. "Reference: from the questionear and the result of the research

\section{Literature review:-}

1- Evaluation of fatty acids daily intake and diets atherogenicity of dietetics students of Wroclaw Medical University.

\section{Our Finding:-}

Average energy intake was $1673.9 \mathrm{kcal}$ per day. The average daily total fat intake was $65.4 \mathrm{~g}$ and provided $34.5 \%$ of total energy intake. The percentage of energy from SFA in the diets of $82 \%$ students exceeded the recommended $10 \%$ and averaged $13.1 \%$. The average percentage of energy from monounsaturated fatty acids (MUFA) in the students diets was $12.9 \%$ and in the diets of 5\% students did not exceeded recommended $10 \%$. The average percentage of energy from polyunsaturated fatty acids (PUFA) was $5.7 \%$ and in the diets of $66 \%$ students did not fulfilled the recommended 6-10\%. About $80 \%$ of the students consumed less than recommended $2 \mathrm{~g}$ of C $18: 3$ per day. Insufficient intake of EPA and DHA was observed in $71 \%$ students' diets. The average $n-6 / n-3$ PUFA ratio was 7.2 and in the $76 \%$ of female diets exceeded the recommended value of $4: 1$. The diets of $80 \%$ of students were considered as atherogenic, because of elevated value of Keys score. The ratio between PUFA and SFA in the female diets was incorrect and amounted to 0.52 (recommended value > 1.0).

\section{Their conclusion:-}

Incorrect energy intake from daily diet and improper dietary intake of selected fatty acids in the diets of students may contribute to the development of CVD.

2-Do our medical colleges inculcate health-promoting lifestyle among medical students: a pilot study from two medical colleges from southern India.

\section{Our Finding:-}

Out of 176 respondents, $94(53 \%)$ were males and $82(47 \%)$ were females. The number of smokers had increased from $24(13.6 \%)$ to $46(26.1 \%)$ and the number of alcohol consumers from $34(19.3 \%)$ to $77(43.8 \%)$ since they joined medical college. The number of students doing any physical activity declined from 76 (43.2\%) to 43 (24.4\%) and their food habits became unhealthier during the same period.

\section{Their Counclusion:-}

The study reported an increase in health-risking behavior and a decline in health-promoting behavior among medical students during their stay in medical college.

\section{3- Schools' Cafeteria Status: Does it Affect Snack Patterns? A Qualitative Study.}

\section{Our findings:-}

Over half of the students believed that snack consumption is necessary. Although, majority of students believed that their schools' cafeterias are not acceptable, they noted them as one of the necessary parts of school. Nearly half of the children were complaining of unvaried and expensive food items. The most purchased items were: Cookies, sandwiches with mayonnaise and ketchup, soft drinks and chocolate milk. Most of the students were interested in having roles in their cafeterias.

Schools' cafeteria are significant sources of supplying adolescents' snacks, so developing hygienic stores containing healthy and nutritious food items is a key element to affect their snack selection positively. Reaching this goal requires a multi disciplinary approach through participation of students, school staff, parents, and the support of community and media.

4- Eating habits and body-weights of students of the university of belgrade, serbia: a cross-sectional study. 


\section{Our finding:-}

Almost every fourth male student was overweight. Strikingly, $15 \%$ of female students were underweight. Highlysignificant difference was found between average body mass index (BMI) of male and female students ( $\mathrm{F}=317.8$, $\mathrm{p}=0.001$ ). Students' BMI did not correlate with average family income or with the frequency of taking breakfast ( $\mathrm{p}=-$ $0.064, \mathrm{p}=0.152$ for males and $\mathrm{p}=0.034, \mathrm{p}=0.282$ for females respectively).

5-Anthropometric traits, blood pressure, and dietary and physical exercise habits in health sciences students; the obesity observatory project.

\section{Our findings:-}

$23.4 \%$ of the participants were overweight and $10 \%$ obese. Parental obesity was the most frequent risk factor, followed by social drinking and smoking. We found high consumption of animal derived foods, breakfast- like cereals, pastries, white bread and sweetened beverages; while low intake of fruit and vegetables were reported. More than half the sample reported to practice very little or no exercise at all.

\section{Their conclusion:-}

We found similar or even higher rates of risk factors than the average population, that may eventually lead to the development of chronic cardiometabolic diseases. Thus we can infer that biomedical education is inefficient in inducing healthy lifestyles among biomedical students, which could have impact in their future practice as they will most probable become obese health-professionals, thus fail to effectively treat their own patients.

6- A Cross-Cultural Comparison of Health Behaviors between Saudi and British Adolescents Living in Urban Areas: Gender by Country Analyses.

\section{Our findings:-}

The overweight/obesity prevalence among Saudi adolescents $(38.3 \%)$ was significantly $(\mathrm{p}<0.001)$ higher than that found among British adolescents (24.1\%). The British adolescents demonstrated higher total PA energy expenditure than Saudi adolescents (means $\pm \mathrm{SE}=3,804.8 \pm 81.5$ vs. 2,219.9 $\pm 65.5 \mathrm{METs}-\mathrm{min} /$ week). Inactivity prevalence was significantly $(\mathrm{p}<0.001)$ higher among Saudi adolescents $(64 \%)$ compared with that of British adolescents (25.5\%). The proportions of adolescents exceeding $2 \mathrm{~h}$ of daily screen time were high $(88.0 \%$ and $90.8 \%$ among Saudis and British, respectively). The majority of Saudi and British adolescents did not have daily intakes of breakfast, fruit, vegetables and milk. MANCOVA showed significant $(\mathrm{p}<0.05)$ gender by country interactions in several lifestyle factors. There was a significant $(\mathrm{p}<0.001)$ gender differences in the ratio of physical activity to sedentary behaviors.

\section{Their conclusion:-}

Saudi and British adolescents demonstrated some similarities and differences in their PA levels, sedentary behaviors and dietary habits. Unhealthy lifestyle behaviors among adolescents appear to be a cross-cultural phenomenon.

\section{Eating Patterns and Physical Activity Characteristics Among Urban and Rural Students in Saudi Arabia}

Their counclusion:- urban youth may be at greater risk for obesity due to urban lifestyle compared to the rural teens. Rural youth who stay with traditional Arabic lifestyle of eating traditional foods, which focus more on fruits, vegetables, low fat dairy and whole grains, and being physical active by walking or farming may be at reduced risk.

\section{Materials and Methods:-}

We conducted a cross-sectional study using an electronic questioner paper among sample of the current available students who are studying the preclinical years At Al-Imam universaity of the yeaer 1434-1435 h.

The sample we are using is simple random sampling; and the students are our desired unit.

The data has been entered and analyzed by using SPSS

\section{Data tools:-}

Since that this is the first research looking for the Dietary patterns among medical student in Al-imam Mohammed bin Saud Islamic university. 
We found ourselves in need to use Primary data In order to scientifically answer our research questions. And to gather the needed Information and after reviewing different collection tools looking at their pros and cons we decided to use electronic questionnaires to present our objectives to be fulfilled by our friends especially that the dietary patterns are a complicated life style thing, we thought it would be better if we let the student take their time in thinking and remembering their food consumption. Instate of e.g. used an interview as collecting tool and a big bias or error may occur as a result of the limited time the interview takes.

\section{Result:-}

We distributed our electronic questioners to the 1st, 2nd and 3rd years by the official e-mail group of these patches. The respondes were 26, 19 and 34 of the 1st, 2nd and 3rd years student.

Age:-

Shown in Table (1) that the highest percentage of age for the first year is the age of 20 years old by $61.5 \%$, and the highest percentage for the second year was the age of 20 years old by $47.4 \%$, and the highest percentage for the third year were age 21 years as $31.4 \%$.

Table 1:- the distribution of the study sample by age.

\begin{tabular}{|c|c|c|c|c|c|c|}
\hline \multirow[t]{2}{*}{ Age } & \multicolumn{2}{|c|}{ First year } & \multicolumn{2}{|c|}{ Second year } & \multicolumn{2}{|c|}{ Third year } \\
\hline & Freq. & $(\%)$ & Freq. & $(\%)$ & Freq. & $(\%)$ \\
\hline 19 & 1 & 3.8 & 3 & 15.8 & - & - \\
\hline 20 & 16 & 61.5 & 9 & 47.4 & - & - \\
\hline 21 & 8 & 30.8 & - & - & 11 & 31.4 \\
\hline 22 & - & - & 3 & 15.8 & 9 & 25.7 \\
\hline 23 & - & - & 1 & 10.5 & 9 & 25.7 \\
\hline 24 & - & - & - & - & 2 & 5.7 \\
\hline 25 & - & - & - & - & 1 & 2.9 \\
\hline 26 & - & - & - & - & 1 & 2.9 \\
\hline 27 & - & - & 1 & 5.3 & - & - \\
\hline 29 & - & - & 1 & 5.3 & - & - \\
\hline 30 & - & - & - & - & 1 & 2.9 \\
\hline 33 & - & - & - & - & 1 & 2.9 \\
\hline 38 & 1 & 3.8 & - & - & - & - \\
\hline Total & 26 & 100 & 19 & 100 & 35 & 100 \\
\hline
\end{tabular}

BMI:-

In our study, as table (2.1) suggest that there are still a high number of overweight and obese students. Around $57.5 \%$ of the sample we collected.

Table 2.1:- distribution of study sample according to BMI.

\begin{tabular}{|l|l|l|}
\hline BMI & Freq. & $(\%)$ \\
\hline underweight & 2 & 2.5 \\
\hline normal & 32 & 40 \\
\hline Overweight & 26 & 32.5 \\
\hline obese & 20 & 25 \\
\hline Total & 80 & 100 \\
\hline
\end{tabular}

Shown in table (1.2) that the highest rate of the first year for normal weight and above the normal was $34.6 \%$ for each of them, and the lowest was for obese by 30.8\%. and the highest rate for the second year was for normal and obese by $42.1 \%$, and the lowest was for less than normal 5.3\% . and the highest rate for the third year was for the normal and above normal by $42.9 \%$ for each of them, and the lowest was for less than the normal by $2.9 \%$.

Table 1.2:- distribution of study sample according to BMI.

\begin{tabular}{|l|l|l|l|l|l|l|}
\hline \multirow{2}{*}{ BMI } & First year & Second year & \multicolumn{2}{l|}{ Third year } \\
\cline { 2 - 8 } & Freq. & $(\%)$ & Freq. & $(\%)$ & Freq. & $(\%)$ \\
\hline underweight & - & - & 1 & 5.3 & 1 & 2.9 \\
\hline normal & 9 & 34.6 & 8 & 42.1 & 15 & 42.9 \\
\hline overweight & 9 & 34.6 & 2 & 10.5 & 15 & 42.9 \\
\hline Obese & 8 & 30.8 & 8 & 42.1 & 4 & 11.4 \\
\hline Total & 26 & 100 & 19 & 100 & 35 & 100 \\
\hline
\end{tabular}

So, to study their food consumption further we found: 


\section{Breakfast:-}

$43.8 \%$ of students have their breakfast before going to the collage as displayed in this table (2.1):

Table 2.1:- Distribution of the study sample according to eating breakfast before going to the University.

\begin{tabular}{|l|l|l|}
\hline Answer & Freq. & $(\%)$ \\
\hline Yes & 35 & 43.8 \\
\hline No & 45 & 56.2 \\
\hline Total & 80 & 100 \\
\hline
\end{tabular}

Shown in table (2.2) that $34.6 \%$ of first year students eat their breakfast before going to the university . and that $36.8 \%$ of the second year students eat their breakfast before going to the university . and also $54.3 \%$ of third year students eat their breakfast before going to the University .

Table 1.6:- Distribution of the study sample according to eating breakfast before going to the University.

\begin{tabular}{|l|l|l|l|l|l|l|}
\hline \multirow{2}{*}{ Answer } & First year & \multicolumn{2}{l|}{ Second year } & \multicolumn{2}{l|}{ Third year } \\
\cline { 2 - 7 } & Freq. & $(\%)$ & Freq. & $(\%)$ & Freq. & $(\%)$ \\
\hline Yes & 9 & 34.6 & 7 & 36.8 & 19 & 54.3 \\
\hline No & 17 & 65.4 & 12 & 63.2 & 16 & 45.7 \\
\hline Total & 26 & 100 & 19 & 100 & 35 & 100 \\
\hline
\end{tabular}

Fast food restaurants:-

As this table (3.2) displayed that's 33.3\% of the sample eats at fast food restaurants 1-3 times a week.

Table 3.1:- Distribution of the study sample by eating at fast food restaurants.

\begin{tabular}{|l|l|l|}
\hline Answer & Freq. & $(\%)$ \\
\hline Yes & $\mathbf{7 2}$ & $\mathbf{9 0}$ \\
\hline No & $\mathbf{8}$ & $\mathbf{1 0}$ \\
\hline Total & $\mathbf{8 0}$ & $\mathbf{1 0 0}$ \\
\hline
\end{tabular}

Table 3.2:- Distribution of the study sample according to the number of times eating at fast food restaurants.

\begin{tabular}{|l|l|l|}
\hline Answer & Freq. & $(\%)$ \\
\hline Once a week & 7 & 9.7 \\
\hline $1-3$ times per week & 24 & 33.3 \\
\hline 4-6 times per week & 21 & 29.2 \\
\hline 7 times and more per week & 20 & 27.8 \\
\hline Total & 72 & 100 \\
\hline
\end{tabular}

Shown in table (3.3) that $88.5 \%$ of first year students eat in fast food restaurants . And $94.7 \%$ of the second year students eat in fast food restaurants, And also $88.6 \%$ of third year students eat in fast food restaurants .

Table 3.3:- Distribution of the study sample by eating at fast food restaurants .

\begin{tabular}{|l|l|l|l|l|l|l|}
\hline \multirow{2}{*}{ Answer } & First year & Second year & \multicolumn{2}{l|}{ Third year } \\
\cline { 2 - 8 } & Freq. & $(\%)$ & Freq. & $(\%)$ & Freq. & $(\%)$ \\
\hline Yes & 23 & 88.5 & 18 & 94.7 & 31 & 88.6 \\
\hline No & 3 & 11.5 & 1 & 5.3 & 4 & 11.4 \\
\hline Total & 26 & 100 & 19 & 100 & 35 & 100 \\
\hline
\end{tabular}

Shown in table (3.4) that the highest rate of first year students rate 39.1\% of ate out 4-6 times a week at fast food restaurants. And the highest rate of second year students is $50 \%$ ate out 1-3 times a week. And the highest rate of third-year students is 29\% eat 1-3 times, 4-6 times, and 7 times or more per week 
Table 3.4:- Distribution of the study sample according to the number of times eating at fast food restaurants.

\begin{tabular}{|l|l|l|l|l|l|l|}
\hline \multirow{2}{*}{ Answer } & First week & \multicolumn{2}{l|}{ Second year } & \multicolumn{2}{l|}{ Third year } \\
\cline { 2 - 7 } & Freq. & $(\%)$ & Freq. & $(\%)$ & Freq. & $(\%)$ \\
\hline Once a week & 1 & 4.3 & 2 & 11.1 & 4 & 12.9 \\
\hline 1-3 times per week & 6 & 26.1 & 9 & 50 & 9 & 29 \\
\hline 4-6 times per week & 9 & 39.1 & 3 & 16.7 & 9 & 29 \\
\hline 7 times and more per week & 7 & 30.4 & 4 & 22.2 & 9 & 29 \\
\hline Total & 23 & 100 & 18 & 100 & 31 & 100 \\
\hline
\end{tabular}

Soft drinks:-

As table (4.2) displayed there's a $37.9 \%$ of the sample are drinking the soft drink more than 7 times a week.

Table 4.1:- Distribution of the study sample by drinking soft drinks.

\begin{tabular}{|l|l|l|}
\hline Answer & Freq. & $(\%)$ \\
\hline Yes & 66 & 82.5 \\
\hline No & 14 & 17.5 \\
\hline Total & 80 & 100 \\
\hline
\end{tabular}

Table 4.2:- Distribution of the study sample according to how many times per week they drink it .

\begin{tabular}{|l|l|l|}
\hline Answer & Freq. & $(\boldsymbol{\%})$ \\
\hline Once a week & $\mathbf{7}$ & $\mathbf{1 0 . 6}$ \\
\hline 1-3 times per week & $\mathbf{1 6}$ & $\mathbf{2 4 . 2}$ \\
\hline 4-6 times per week & $\mathbf{1 8}$ & $\mathbf{2 7 . 3}$ \\
\hline 7 times and more per week & $\mathbf{2 5}$ & $\mathbf{3 7 . 9}$ \\
\hline Total & $\mathbf{6 6}$ & $\mathbf{1 0 0}$ \\
\hline
\end{tabular}

Shown in table (4.3) that $88.5 \%$ of first-year students are drinking soft drinks, and $68.4 \%$ of second-year students also drink a soft, and $85.7 \%$ of third-year students drink a soft drinks Also

Table 4.3:- Distribution of the study sample by drinking soft drinks.

\begin{tabular}{|l|l|l|l|l|l|l|}
\hline \multirow{2}{*}{ Answer } & First year & \multicolumn{2}{l|}{ Second year } & \multicolumn{2}{l|}{ Third year } \\
\cline { 2 - 8 } & Freq. & $(\%)$ & Freq. & $(\%)$ & Freq. & $(\%)$ \\
\hline Yes & 23 & 88.5 & 13 & 68.4 & 30 & 85.7 \\
\hline No & 3 & 11.5 & 6 & 31.6 & 5 & 14.3 \\
\hline Total & 26 & 100 & 19 & 100 & 35 & 100 \\
\hline
\end{tabular}

Shown in table (4.4) that $39.1 \%$ of first year students are drinking soft drinks from 4-6 times a week . and $38.5 \%$ of second year students drinking soft drinks more than 7 times per week, and $43.3 \%$ of third year students are drinking soft drinks 7 times or more a week.

Table 4.4:- Distribution of the study sample according to how many times per week they drink it.

\begin{tabular}{|l|l|l|l|l|l|l|}
\hline \multirow{2}{*}{ Answer } & First year & \multicolumn{2}{l|}{ Second year } & \multicolumn{2}{l|}{ Third year } \\
\cline { 2 - 7 } & Freq. & $(\%)$ & Freq. & $(\%)$ & Freq. & $(\%)$ \\
\hline Once a week & 2 & 8.7 & 1 & 7.7 & 4 & 13.3 \\
\hline $1-3$ times per week & 5 & 21.7 & 3 & 23.1 & 8 & 26.7 \\
\hline 4-6 times per week & 9 & 39.1 & 4 & 30.8 & 5 & 16.7 \\
\hline 7 times and more per week & 7 & 30.4 & 5 & 38.5 & 13 & 43.3 \\
\hline Total & 23 & 100 & 13 & 100 & 30 & 100 \\
\hline
\end{tabular}

\section{Energy drinks:-}

As shown in table (5.2) that's $57.9 \%$ of the sample consume energy drinks once a week 
Table 5.1:- Distribution of the study sample according to drinking the energy drinks.

\begin{tabular}{|l|l|l|}
\hline Answer & Freq. & $(\%)$ \\
\hline Yes & 19 & 23.8 \\
\hline No & 61 & $\mathbf{7 6 . 3}$ \\
\hline Total & $\mathbf{8 0}$ & $\mathbf{1 0 0}$ \\
\hline
\end{tabular}

Table 5.2:- Distribution of the study sample according to the number of times drinking the energy drinks.

\begin{tabular}{|l|l|l|}
\hline Answer & Freq. & $(\mathbf{\%})$ \\
\hline Once a week & $\mathbf{1 1}$ & $\mathbf{5 7 . 9}$ \\
\hline 1-3 times per week & $\mathbf{5}$ & $\mathbf{2 6 . 3}$ \\
\hline 4-6 times per week & $\mathbf{3}$ & $\mathbf{1 5 . 8}$ \\
\hline 7 times and more per week & - & - \\
\hline Total & $\mathbf{1 9}$ & $\mathbf{1 0 0}$ \\
\hline
\end{tabular}

Shown in table (5.3) that $26.9 \%$ of first year students are drinking energy drinks . and $31.6 \%$ of the second year students also drinking energy drinks . and also $17.1 \%$ of third-year students are drink energy drinks .

Table 5.3:- Distribution of the study sample according to drinking the energy drinks.

\begin{tabular}{|l|l|l|l|l|l|l|}
\hline \multirow{2}{*}{ Answer } & First year & \multicolumn{2}{l|}{ Second year } & \multicolumn{2}{l|}{ Third year } \\
\cline { 2 - 7 } & Freq. & $(\%)$ & Freq. & $(\%)$ & Freq. & $(\%)$ \\
\hline Yes & 7 & 26.9 & 6 & 31.6 & 6 & 17.1 \\
\hline No & 19 & 73.1 & 13 & 68.4 & 29 & 82.9 \\
\hline Total & 26 & 100 & 19 & 100 & 35 & 100 \\
\hline
\end{tabular}

Shown in table (5.4) that $71.4 \%$ of first year students are drinking energy drinks once a week .And $50 \%$ of second year students also are drinking energy drinks once a week . and also 50\% of third year students are drinking energy drinks once a week

Table 5.4:- Distribution of the study sample according to the number of times drinking the energy drinks.

\begin{tabular}{|l|l|l|l|l|l|l|}
\hline \multirow{2}{*}{ Answer } & First year & \multicolumn{3}{l|}{ Second year } & \multicolumn{2}{l|}{ Third year } \\
\cline { 2 - 8 } & Freq. & $(\%)$ & Freq. & $(\%)$ & Freq. & $(\%)$ \\
\hline Once a week & 5 & 71.4 & 3 & 50 & 3 & 50 \\
\hline $1-3$ times per week & 1 & 14.3 & 2 & 33.3 & 2 & 33.3 \\
\hline 4-6 times per week & 1 & 14.3 & 1 & 16.7 & 1 & 16.7 \\
\hline 7 times and more per week & - & - & - & - & - & - \\
\hline Total & 7 & 100 & 6 & 100 & 6 & 100 \\
\hline
\end{tabular}

Fruits and vegetables -

As shown in table (6.1) that's $45 \%$ of the sample eat fruits and vegetables 1-3 times a week.

Table 6.1:- Distribution of the study sample according to the number of times of eating fruits and vegetables .

\begin{tabular}{|l|l|l|}
\hline Answer & Freq. & $\mathbf{( \% )}$ \\
\hline Once a week & $\mathbf{2 1}$ & $\mathbf{2 6 . 3}$ \\
\hline 1-3 times per week & $\mathbf{3 6}$ & $\mathbf{4 5}$ \\
\hline 4-6 times per week & $\mathbf{1 7}$ & $\mathbf{2 1 . 3}$ \\
\hline 7 times and more per week & $\mathbf{6}$ & $\mathbf{7 . 5}$ \\
\hline Total & $\mathbf{8 0}$ & $\mathbf{1 0 0}$ \\
\hline
\end{tabular}

Shown in the table (6.2) that 50\% of first year students eat fruits and vegetables 1-3 times a week . and 57.9\% of second year students also eat fruits and vegetables 1-3 times a week . and 40\% of third year students eat fruits and vegetables once weekly . 
Table 6.2:- Distribution of the study sample according to the number of times of eating fruits and vegetables.

\begin{tabular}{|l|l|l|l|l|l|l|}
\hline \multirow{2}{*}{ Answer } & First year & \multicolumn{2}{l|}{ Second year } & \multicolumn{2}{l|}{ Third year } \\
\cline { 2 - 7 } & Freq. & $(\%)$ & Freq. & $(\%)$ & Freq. & $(\%)$ \\
\hline Once a week & 5 & 19.2 & 2 & 10.5 & 14 & 40 \\
\hline $1-3$ times per week & 13 & 50 & 11 & 57.9 & 12 & 34.3 \\
\hline 4-6 times per week & 4 & 15.4 & 5 & 26.3 & 8 & 22.9 \\
\hline 7 times and more per week & 4 & 15.4 & 1 & 5.3 & 1 & 2.9 \\
\hline Total & 26 & 100 & 19 & 100 & 35 & 100 \\
\hline
\end{tabular}

Milk and milk products:-

As shown in table (7.1) that's $30 \%$ of the sample consume milk or milk products from 1-3 times a week.

Table 7.1:- Distribution of the study sample according to the number of times taking milk or milk products.

\begin{tabular}{|l|l|l|}
\hline Answer & Freq. & $\mathbf{( \% )}$ \\
\hline Once a week & $\mathbf{1 2}$ & $\mathbf{1 5}$ \\
\hline 1-3 times per week & $\mathbf{2 4}$ & $\mathbf{3 0}$ \\
\hline 4-6 times per week & $\mathbf{2 3}$ & $\mathbf{2 8 . 8}$ \\
\hline 7 times and more per week & $\mathbf{2 1}$ & $\mathbf{2 6 . 2}$ \\
\hline Total & $\mathbf{8 0}$ & $\mathbf{1 0 0}$ \\
\hline
\end{tabular}

Shown in table (7.2) that 34.6\% of first year students taking milk or milk products 7 times or more per week . And $31.6 \%$ from the second year students take milk or milk products 1-3 times a week as well as from 4-6 times a week, as well as 7 times or more per week. And 31.4\% of third year students take milk or milk products from 4-6 times a week .

Table 7.2:- Distribution of the study sample according to the number of times taking milk or milk products.

\begin{tabular}{|l|l|l|l|l|l|l|}
\hline \multirow{2}{*}{ Answer } & First year & \multicolumn{2}{l|}{ Second year } & \multicolumn{2}{l|}{ Third year } \\
\cline { 2 - 7 } & Freq. & $(\%)$ & Freq. & $(\%)$ & Freq. & $(\%)$ \\
\hline Once a week & 3 & 11.5 & 1 & 5.3 & 8 & 22.9 \\
\hline $1-3$ times per week & 8 & 30.8 & 6 & 31.6 & 10 & 28.6 \\
\hline 4-6 times per week & 6 & 23.1 & 6 & 31.6 & 11 & 31.4 \\
\hline 7 times and more per week & 9 & 34.6 & 6 & 31.6 & 6 & 17.1 \\
\hline Total & 26 & 100 & 19 & 100 & 35 & 100 \\
\hline
\end{tabular}

\section{Proteins:-}

As shown in table (8.1) that's $45 \%$ of the sample eat proteins 7 times and more a week.

Table 8.1:- Distribution of the study sample according to how often they eat proteins .

\begin{tabular}{|l|l|l|}
\hline Answer & Freq. & $\mathbf{( \% )}$ \\
\hline Once a week & $\mathbf{1}$ & $\mathbf{1 . 3}$ \\
\hline 1-3 times per week & $\mathbf{2 0}$ & $\mathbf{2 5}$ \\
\hline 4-6 times per week & $\mathbf{2 3}$ & $\mathbf{2 8 . 7}$ \\
\hline 7 times and more per week & $\mathbf{3 6}$ & $\mathbf{4 5}$ \\
\hline Total & $\mathbf{8 0}$ & $\mathbf{1 0 0}$ \\
\hline
\end{tabular}

Shown in table (8.2) that $65.4 \%$ of first year students eat proteins 7 times and more .And $36.8 \%$ of second year students eat proteins 7 times or more per week. And $34.4 \%$ of third year students eat proteins from 1-3 times a week . and as well as 7 times or more a week

Table 8.2:- Distribution of the study sample according to how often they eat proteins.

\begin{tabular}{|l|l|l|l|l|l|l|}
\hline \multirow{2}{*}{ Answer } & First year & \multicolumn{2}{l|}{ Second year } & \multicolumn{2}{l|}{ Third year } \\
\cline { 2 - 7 } & Freq. & $(\%)$ & Freq. & $(\%)$ & Freq. & $(\%)$ \\
\hline Once a week & - & - & - & - & 1 & 2.9 \\
\hline 1-3 times per week & 2 & 7.7 & 6 & 31.6 & 12 & 34.3 \\
\hline 4-6 times per week & 7 & 26.9 & 6 & 31.6 & 10 & 28.6 \\
\hline 7 times and more per week & 17 & 65.4 & 7 & 36.8 & 12 & 34.3 \\
\hline Total & 26 & 100 & 19 & 100 & 35 & 100 \\
\hline
\end{tabular}




\section{Bread or cereal:-}

As Shown in table (9.1) that $47.5 \%$ of the sample eat bread and cereals 7 times or more per week .

Table 9.1:- Distribution of the study sample according to the number of times eating bread or cereal .

\begin{tabular}{|l|l|l|}
\hline Answer & Freq. & $(\boldsymbol{\%})$ \\
\hline Once a week & $\mathbf{3}$ & $\mathbf{3 . 8}$ \\
\hline 1-3 times per week & $\mathbf{1 4}$ & $\mathbf{1 7 . 5}$ \\
\hline 4-6 times per week & $\mathbf{2 5}$ & $\mathbf{3 1 . 2}$ \\
\hline 7 times and more per week & $\mathbf{3 8}$ & $\mathbf{4 7 . 5}$ \\
\hline Total & $\mathbf{8 0}$ & $\mathbf{1 0 0}$ \\
\hline
\end{tabular}

Shown in table (9.2) that $65.4 \%$ of first year students eat bread and cereals 7 times or more per week . and $42.1 \%$ from the second year students are eating bread and cereal from 4-6 times a week. and $40 \%$ of third year students eat bread and cereals 7 times or more per week .

Table 9.2;- Distribution of the study sample according to the number of times eating bread or cerea.l

\begin{tabular}{|l|l|l|l|l|l|l|}
\hline \multirow{2}{*}{ Answer } & \multicolumn{3}{l|}{ First year } & \multicolumn{2}{l|}{ Second year } & \multicolumn{2}{l|}{ Third year } \\
\cline { 2 - 7 } & Freq. & $(\%)$ & Freq. & $(\%)$ & Freq. & $(\%)$ \\
\hline Once a week & 2 & 7.7 & - & - & 1 & 2.9 \\
\hline 1-3 times per week & 3 & 11.5 & 4 & 21.1 & 7 & 20 \\
\hline 4-6 times per week & 4 & 15.4 & 8 & 42.1 & 13 & 37.1 \\
\hline 7 times and more per week & 17 & 65.4 & 7 & 36.8 & 14 & 40 \\
\hline Total & 26 & 100 & 19 & 100 & 35 & 100 \\
\hline
\end{tabular}

\section{Snacks:-}

As Shown in table (10.2) that 39.3\% of the sample eats snacks from 1-3 times a week.

Table 10.1:- Distribution of the study sample as eating snacks between meals.

\begin{tabular}{|l|l|l|}
\hline Answer & Freq. & $(\%)$ \\
\hline Yes & 61 & $\mathbf{7 6 . 2}$ \\
\hline No & 19 & 23.8 \\
\hline Total & 80 & 100 \\
\hline
\end{tabular}

Table 10.2:- Distribution of the study sample according to how many times per day they eat a snacks.

\begin{tabular}{|l|l|l|}
\hline Answer & Freq. & $\mathbf{( \% )}$ \\
\hline Once a day & $\mathbf{4}$ & $\mathbf{6 . 6}$ \\
\hline 1-3 times per day & $\mathbf{2 4}$ & $\mathbf{3 9 . 3}$ \\
\hline 4-6 times per day & $\mathbf{1 7}$ & $\mathbf{2 7 . 9}$ \\
\hline 7 times and more per day & $\mathbf{1 6}$ & $\mathbf{2 6 . 2}$ \\
\hline Total & $\mathbf{6 1}$ & $\mathbf{1 0 0}$ \\
\hline
\end{tabular}

Shown in table (10.3) that $80.8 \%$ of first year students eat snacks between meals . and $57.9 \%$ of the second year students eat snacks between meals. and also $82.9 \%$ of third year students eat snacks between meals .

Table 10.3:- Distribution of the study sample as eating snacks between meals.

\begin{tabular}{|l|l|l|l|l|l|l|}
\hline \multirow{2}{*}{ Answer } & First year & \multicolumn{2}{l|}{ Second year } & \multicolumn{2}{l|}{ Third year } \\
\cline { 2 - 7 } & Freq. & $(\%)$ & Freq. & $(\%)$ & Freq. & $(\%)$ \\
\hline Yes & 21 & 80.8 & 11 & 57.9 & 29 & 82.9 \\
\hline No & 5 & 19.2 & 8 & 42.1 & 6 & 17.1 \\
\hline Total & 26 & 100 & 19 & 100 & 35 & 100 \\
\hline
\end{tabular}

Shown in table (10.4) that $47.6 \%$ of first year students eat snacks from 1-3 times a week .And $54.5 \%$ of second year students are eating snacks from 4-6 times a week. And also $44.8 \%$ of third year students eat snacks 1-3 times a week . 
Table 10.4:- Distribution of the study sample according to how many times per day they eat a snacks.

\begin{tabular}{|l|l|l|l|l|l|l|}
\hline \multirow{2}{*}{ Answer } & First year & \multicolumn{2}{l|}{ Second year } & Third year \\
\cline { 2 - 7 } & Freq. & $(\%)$ & Freq. & $(\%)$ & Freq. & $(\%)$ \\
\hline Once a week & 2 & 9.5 & - & - & 2 & 6.9 \\
\hline 1-3 times per week & 10 & 47.6 & 1 & 9.1 & 13 & 44.8 \\
\hline 4-6 times per week & 4 & 19 & 6 & 54.5 & 7 & 24.1 \\
\hline 7 times and more per week & 5 & 23.8 & 4 & 36.4 & 7 & 24.1 \\
\hline Total & 21 & 100 & 11 & 100 & 29 & 100 \\
\hline
\end{tabular}

\section{Discussion:-}

World widely there is so many data and research conclude that there is an increase of fatty consumption among university student. Suggested an increased risk of overweight and obesity among these populations.

In our study, as table 3.1 suggest that there's still a high number of overweight and obese students. Around $57.5 \%$ of the sample we collected.

Table 3.1:-

\begin{tabular}{|l|l|l|}
\hline BMI & Freq. & $(\%)$ \\
\hline underweight & 2 & 2.5 \\
\hline normal & 32 & 40 \\
\hline Over weight & 26 & 32.5 \\
\hline obese & 20 & 25 \\
\hline Total & 80 & 100 \\
\hline
\end{tabular}

Studying there food consumption we found theres an increase fatty acide consumption based on the regular consumption of fast food restaurants $90 \%$ at least once aweek, soft drinks $37.9 \%$ more than 7 times a week, enrgy drink $57.9 \%$ at least once a week etc. on the other hand there a slightly decrease of natural healthy food e.g. that's $30 \%$ of the sample consume milk or milk products from 1-3 times a week. For example the 2nd year shows the majorty of the prvlence of obesity among them compared to the other years but yet there's no big difrence in food consumption with the 3rd year which is the least of the prvlance of obesity among them. there's still no clear conclusion of the relationship of the food consumption and the overweight and obesity research. Further studies are needed on this subject.

\section{Conclusion:-}

The prevalence of obesity and overweight was high in our study of $57.5 \%(65.4 \%, 52.6 \%$ and $54.3 \%$ of 1 st , 2nd and 3rd years). so many data suggest that it is a growing problem. there's still no clear conclusion of the relationship of the food consumption and the overweight and obesity research. Further studies are needed on this subject.

\section{Recommendation:-}

1. More researches needed including more batches in the college with higher sample.

2. There should be awareness for the high prevlance of overweight and obesty.

\section{References:-}

1. Abahusain, M., Wright, J., Dickerson, J. and de Vol, E. (1999): Retinol, $\alpha$ - tocopherol and carotenoids in diabetes. European Journal of Clinical Nutrition, 53: 630-635.

2. Abahussain, N. (1999): Nutritional status of adolescent girls in the eastern province of Saudi Arabia. Nutrition Health, 13: 1717.

3. Abalkhail, B., Ghabrah, T. and Al bar, H. (1998): Cardiovascular disease health risk appraisal in King Abdulaziz University. Jeddah Journal KAU, Medical Science, 7: 57-66.

4. Abdel-Megeid, F., Abdelkarem, H. and El Fetouh, A. (2011): Unhealthy nutritional habits in University students are risk factors for cardiovascular diseases. Saudi Medical Journal, 32: 621-627.

5. Aguirre, R. and May, J. (2008): Inflammation in the vascular bed: importance of vitamin C. Pharmacology and Therapeutics, 119: 96-103. 
6. Al Assaf, A. (2007): Anemia and iron intake of adult Saudis in Riyadh city, Saudi Arabia. Pakistan Journal of Nutrition, 6: 355-358.

7. Al Assaf, A. and Al Numair, K. (2007): Body mass index and dietary intake of Saudi adult males in the Riyadh region- Saudi Arabia. Pakistan Journal of Nutrition, 6: 414-418.

8. Al Bassan, R., Gawwad, E. and Khanam, L. (2007): weight management practices and their relationship to knowledge perception and health student of Saudi females attending diet clinics in Riyadh city. Journal Egypt Public Health Association, 82: 173-201.

9. Al Daghri, N., Al Othman, A., Al Kharfy, K., Al Okail, M., Khan, N., Al Fawaz, H., Aiswaidan, I. and Chrousos, G. (2012): Assessment of selected nutrient intake and adipocytokine profile among Saudi children and adults. Endocrine Journal, 59: 1057-1063.

10. Al Dossary, A., While, A. and Barriball, L. (2008): Health care and nursing in Saudi Arabia. International Nursing Review, 55: 125-128.

11. Al Farhan, A. (2011): Dietary intake of Arab international students in Northeast Ohio. Ohio, USA, Master thesis, Kent State University.

12. Al Fawaz, H. (2012): The relationship between fast food consumption and BMI among University female students. Pakistan Journal of Nutrition, 11: 406-410.227.

13. Al Habori, M., Al Mamari, M. and Al Meeri, A. (2004): Type II diabetes mellitus and impaired glucose tolerance in Yemen: prevalence associated metabolic changes and risk factors. Diabetes Research and Clinical Practice, 65: 275-281.

14. Al Hamdan, A., Al Huthail, R., Al Saif, M., Al Othman, A., Al Muammer, M., Al Orf, S, Saeed, A. and Mohamed, B. (2009): The effect of weight reduction diet on C - reactive protein level in obese adult subjects. Journal of Medical science, 9: 17-23.

15. Al Harbi, M. (2004): Dietary factors and chronic diseases association with living in the Kingdom of Saudi Arabia. Arab Journal of food and Nutrition, 5: 38-46.

16. Al Hazmi, M. and Warsy, A. (1999): Relationship between obesity, overweight and plasma lipid in Saudi. Saudi Medical Journal, 20: 512-525.

17. Al Hazmi, M. and Warsy, A. (2002): The prevalence of obesity and overweight in 1-18 year old Saudi children. Annals Saudi Medical, 22: 303-307.

18. Al Hazzaa, H. (2004): Prevalence of physical inactivity in Saudi Arabia: a brief review. Eastern Mediterranean Health Journal, 10: 663-670.

19. Al Hazzaa, H. (2006): school back pack: how much load do Saudi boys carry on their shoulders? Saudi Medical Journal, 27: 1567-1571.

20. Al Herbish, A., Al Nuaim, A. and Bamgboye, E. (1996): The pattern of growth and obesity in Saudi Arabian male school children. International Journal of Obesity, 20: 1000-1005.

21. Al Hosani, E. and Rugg-Gunn, A. (2000): The relationship between diet and dental caries in 2 and 4 years old children in the Emirate of Abu-Dhabi. Saudi Dental Journal, 12: 149-155.

22. Al Kanhal, M., Al Mohizea, I., Al Othaimeen, A. and Khan, M. (1994): Nutritive value of some wheat based dishes consumed in the Kingdom of Saudi Arabia. Ecology of Food and Nutrition, 32: 219-226.

23. Al Kanhal, M., Al Mohizea, I., Al Othaimeen, A. and Khan, M. (1998): Nutritional evaluation of some legume based dishes consumed in Saudi Arabia. International Journal of Food Sciences and Nutrition, 49: 193-197.

24. Al Kanhal, M., Al Mohizea, I., Al Othaimeen, A. and Khan, M. (1999a): Nutritive value of various breads in Saudi Arabia. International Journal of Food Sciences and Nutrition, 50: 345-349.

25. Al Kanhal, M., Al Mohizea, I., Al Othaimeen, A. and Khan, M. (1999b): Nutritive value of various rice based dishes in Saudi Arabia. Ecology of and Nutrition, 38: 223-235.228

26. Al Kasab, F., Alkafajei, A. and Medbigh, S. (1979): The prevalence of diabetes mellitus in a rural community in Iraq. International Journal of Epidemiology, 8: 69-71.

27. Al Khamees, N. (2009): Food habits of university nutrition students: pilot study. Nutrition and Food Science, 39: 499-502.

28. Al Khateeb, B. and AL Gelban, K. (2008): Dietary habits in a suburban Saudi community. Biomedical Research, 19: 55-59.

29. Al Mahroos, F. and Al Roomi, K. (1999): Overweight and obesity in the Arabian Peninsula: an overview. Journal of the Royal Society for the Promotion of Health, 119: 251-253.

30. Al Nakeeb, Y., Lyons, M., Collins, P., Al Nuaim, A., Al Hazzaa, H., Duncan, M. and Nevill, A. (2012): Obesity, Physical Activity and Sedentary Behavior Amongst British and Saudi Youth: A Cross-Cultural Study. International journal of environmental research and public health, 9: 1490-1506. 
31. Al Nozha, M., Al Hazzaa, H., Arafah, M., Al Khadra, A., Al Mazrou, Y., Al Moatouq, M., Khan, N., Al Marzouki, K., Al Harthi, S., Abdullah, M. and Al Shauid, M. (2007a): Prevalence of physical activity and inactivity among Saudi aged 30-70 years, A population based cross sectional study. Saudi Medical Journal, 28: 559-568.

32. Al Nozha, M., Al Kanhal, M., Al Othaimeen, A., Al Mohizea I., Osman, A., Al Shammery, A. and El Shabray, M. (1996): Evaluation of nutritional status of the people of Saudi Arabia, (Unpublished).

33. Al Nozha, M., Al Maatouq, M., Al Mazrou, Y., Al Harthi, S., Arafah, M., Khalil, M., Khan, N., Al Khadra, A., Al Marzouki, K., Nouh, M., Abdullah, M., Attas, O., Al Shauid, M. and Al Mobeireek, A. (2004): Diabetes mellitus in Saudi Arabia. Saudi Medical Journal, 25: 1603-1610.

34. Al Nozha, M., Al Mazrou, Y., Arafah, M., Al Maatouq, M., Khalil, M., Khan, N., Al Khadra, A., Al Marzouki, K., Al Harthi, S., Abdullah, M., Al Shahid, M., Al Mobeireek, A. and Nouh, M. (2005): Obesity in Saudi Arabia. Saudi Medical Journal, 26: 824-829.

35. Al Nozha, M., Al Mazrou, Y., Arafah, M., Al Maatouq, M., Khalil, M., Khan, N., Al Khadra, A., Al Marzouki, K., Al Harthi, S., Abdullah, M., Al Shahid, M., Al Mobeireek, A. and Nouh, M. (2009): Smoking in Saudi Arabia and its relation to coronary artery disease. Journal of the Saudi Heart Association, 21: 169-176.

36. Al Nozha, M., Arafah, M., Al Maatouq, M., Khalil, M., Khan, N., Al Marzouki, K., Al Mazrou, Y., Abdullah, M., Al Khadra, A., Al Harthi, S., Al Shahid, M., Al Mobeireek, A. and Nouh, M. (2008): Hyperlipidemia in Saudi Arabia. Saudi Medical Journal, 29: 282-287.229

37. Al Nozha, M., Moheeb, A., Mohammed, R., Mohamed, Z., Nazeer, B., Yaqoub, Y., Mohammed, A., Marzouki, K., Khadra, A., Saad, A., Al Shahid, M. and Abdulellab, M. (2007b): Hypertension in Saudi Arabia. Saudi Medical Journal, 28: 77-84.

38. Al Nuaim, A. (1997a): Population-based epidemiological study of the prevalence of overweight and obesity in Saudi Arabia, regional variation. Annals of Saudi Medicine, 17: 195-199.

39. Al Nuaim, A. (1997b): High prevalence of metabolic risk factors for cardiovascular diseases among Saudi population, aged 30-64 years. International Journal of Cardiology, 62: 227-235.

40. Al Nuaim, A., Al Rubeaan, K., Al Mazrou, Y., Al Attas, O. and Al Daghari, N. (1996): Prevalence of hypercholesterolemia in Saudi Arabia, epidemiological study. International Journal of Cardiology, 54: 41-49.

41. Al Numair, K. (2006): Copper and zinc status in healthy volunteers living in Saudi Arabia. Journal of Medical Sciences, 6: 519-527.

42. Al Numair, K. (2009): Evaluation of vitamin B6 status of adult Saudis in Al Qassim region- Saudi Arabia. Pakistan Journal of Nutrition, 8: 923-927.

43. Al Numair, K., Al Saif, M., Barber-Heidal, K. and Govindasary, C. (2011): Effects of omega 3 and omega 6 fatty acids on lipids panel in Riyadh city Saudi Arabia. Asia Life Sciences, 20: 477-489.

44. Al Numair, K., Lewis, N. and Evans, 